\title{
Os jovens brasileiros em tempos de covid-19
}

\section{Brazilian youth in times of covid-19}

Lila cristina Xəvier LUz* Marisa Feffermann ** Miriam Abramovay*** Nilson weisheimer ${ }^{* * * *}$ Maria D’Alva Macedo Ferieila******
Fiancisca verônica cavalcante******* Ana paula da silva******* Isabel cistina Lopes L******* $^{* \text {. }}$

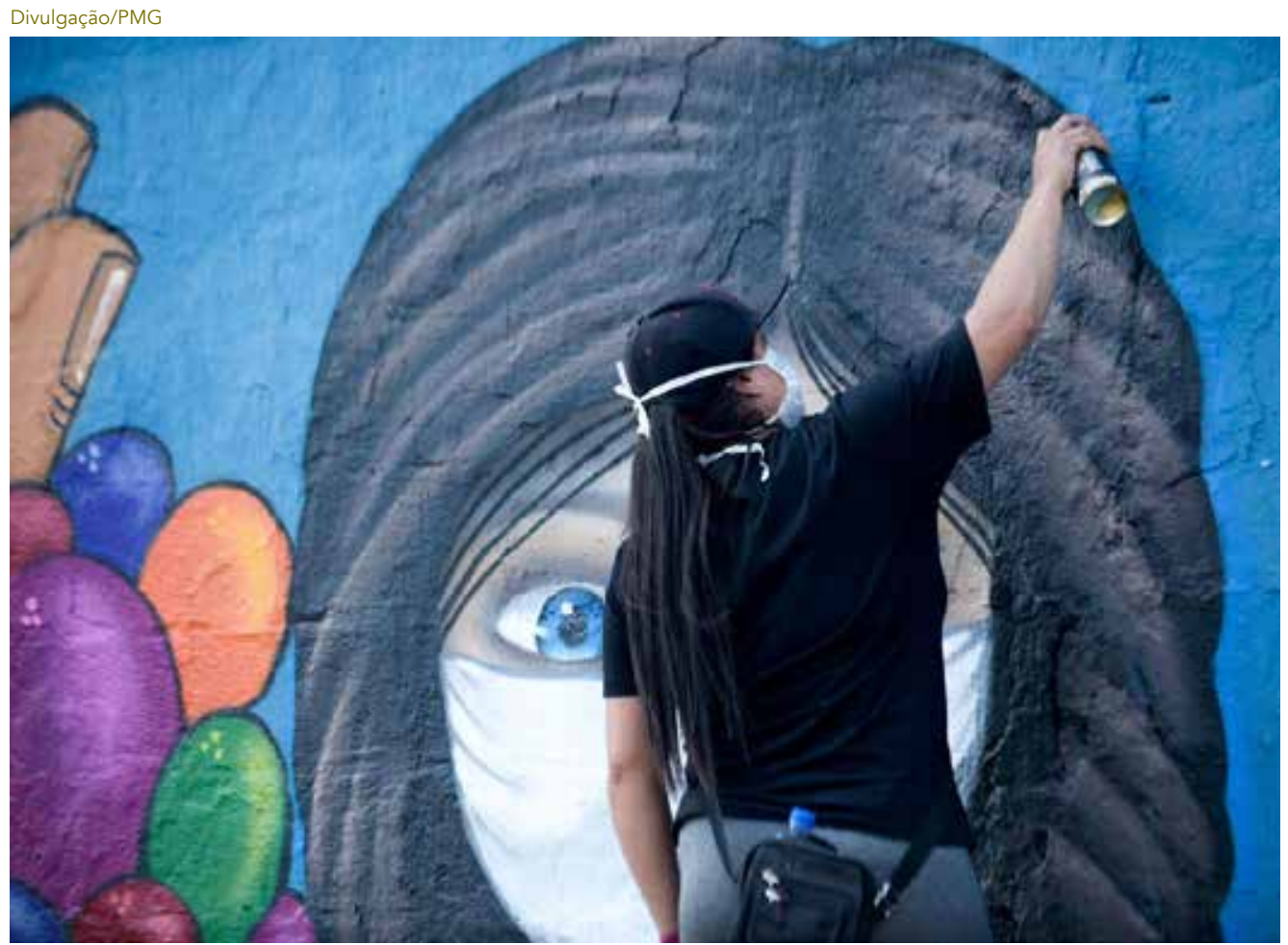




\section{RESUMO}

O artigo aborda o impacto da covid-I9 na vida de jovens brasileiros. Com base em resultados preliminares da pesquisa "Trajetórias/práticas juvenis em tempos de pandemia da covid-I9", traz reflexões sobre como os e as jovens estão vivenciando a educação e o trabalho em tempos de isolamento social, assim como as percepções dos jovens sobre o futuro e as formas de existência e resistência neste contexto. Como resultado, destaca como as persistentes vulnerabilidades sociais, que afetam largas parcelas da juventude brasileira, foram aguçadas com a pandemia.

Palavras-chave: Juventude. Covid-I9. Educação. Trabalho. Futuro.

\section{ABSTRACT}

The article discusses the impact of covid-19 on the lives of Brazilian youth. Based on preliminary results of the investigation "Trajectories/ youth practices in times of covid-I9 pandemic", introduces reflections on how young people are experiencing education and work in times of social isolation; as well as young people's perceptions about the future and the forms of existence and resistance in this context. As a result, it highlight how the persistent social vulnerabilities, which affect large portions of Brazilian youth, were heightened with the pandemic.

Keywords: Youth. Covid-I9. Education. Work. Future. 


\section{INTRODUÇ̃̃o}

Neste artigo nos propomos a compreender como a atual pandemia de covid-I9 está impactando a vida de jovens brasileiros. Reconhecendo que estamos vivendo um fenômeno multidimensional, objetivamos tecer uma reflexão sobre como os jovens percebem o momento atual e lidam com ele. Articulamos essa reflexão em torno de eixos tais como: a identificação de nexos causais entre desigualdades sociais e vulnerabilidade ao adoecimento por covid-I9; a educação e o trabalho em tempos de distanciamento físico; as formas de existência e resistência nesse contexto; assim como as percepções de jovens sobre o futuro.

As informações que nortearam a análise estão ancoradas na pesquisa "Trajetórias/práticas juvenis em tempos de pandemia da covid-ı9", que tem como objetivo conhecer trajetórias e práticas juvenis em tempos de covid-ı9 a partir da interface entre condição juvenil, subjetividades, distanciamento social e práticas cotidianas.

Diferentes preocupações motivaram o interesse pelo desenvolvimento deste estudo. O discurso da natureza democrática da doença, norteador da identificação dos jovens como o grupo menos vulnerável ao coronavírus, esteve sempre em nossos horizontes, além de servir para ocultar o fato de que, antes do início da crise de covid-I9, as pessoas mais jovens já se caracterizavam por uma taxa de exclusão social superior às das demais faixas etárias. Em ruptura com o senso comum, que semeou a ilusão de que elas estariam menos vulneráveis à covid-I9 do que outros grupos etários da população, procuramos evidenciar como as persistentes vulnerabilidades sociais, que afetam largas parcelas da juventude brasileira, foram aguçadas com a pandemia.

A investigação foi iniciada quase ao mesmo tempo que a pandemia. Em desenvolvimento desde março do corrente ano por uma equipe de pesquisadoras de diferentes áreas de conhecimento, a investigação tem possibilitado a construção de um conhecimento interdisciplinar sobre o fenômeno. Para compreender como os e as jovens estão vivenciando os tempos de covid-I9, se considerou fundamental exercer uma escuta atenta de suas narrativas, representações e sentimentos.

Procedemos, assim, a uma pesquisa qualitativa, mediante a realização de entrevistas on-line com indivíduos de 13 a 29 anos de idade, em diferentes situações juvenis. Até o momento esse instrumento alcançou informantes situados em seis estados brasileiros: Bahia, Espírito Santo, Pernambuco, Piauí, Rio de Janeiro e São Paulo. O acesso aos jovens foi obtido com o recurso da estratégia da bola de neve, uma técnica de amostragem não probabilística pela qual recorremos aos próprios jovens para que convidassem os novos participantes da pesquisa. Uma espécie de articulação em rede

Essa iniciativa buscou convergir esforços de pesquisadores de quatro instituições no Brasil: Flacso-Brasil, Instituto de Saúde-SP, UFPI e UFRB. Foi desenvolvida sob a coordenação de Miriam Abramovay, da Flacso, Marisa Feffermann, do Instituto de Saúde-SP, e Lila Cristina Luz, da UFPI. Compõem a equipe as pesquisadoras Ana Paula da Silva, da Flacso, Isabel Cristina Lopes, do Instituto de Saúde-SP, Maria D’Alva Macedo e Francisca Verônica Cavalcante, da UFPI, e o pesquisador Nilson Weisheimer, da UFRB. A pesquisa também está sendo desenvolvida em mais seis países: Argentina, Chile, Cuba, Equador, México e Uruguai, articulando-se unidades da Flacso de cada um desses países sob a coordenação da Flacso-Brasil. 
de amigos e conhecidos. As entrevistas foram mediadas pelo uso de equipamentos como smartphone, gravador ou desktop. Em prol da interação com os entrevistados, esses equipamentos serviram para realizar chamadas de áudio e/ou vídeo para favorecer o diálogo e a entrevista (PORTELLI, 2017), para provocar uma sinergia no contar e escutar sobre o impacto da pandemia na vida dos e das jovens, observando-se formas de expressão por sons, feições, olhares, silêncios, entre outros. Esse procedimento trouxe também algumas dificuldades adicionais ao trabalho de campo inerentes à copresença em espaços virtuais, como o limite de conectividade na rede de computadores, por exemplo. Contudo, esse procedimento nos permitiu estabelecer um dialogo em profundidade com jovens de diferentes lugares e contextos sociais.

A entrevista foi orientada por um roteiro com questões abertas, focadas no cotidiano dos jovens, suas sociabilidades, percepções, sentimentos, crenças, cuidados, violências enfrentadas, lazer, acesso a mídias sociais. Nesse sentido, refletir acerca das consequências da pandemia para as sociabilidades juvenis e sobre as expectativas pós-pandemia é um desafio por demais complexo, ante as incertezas quanto ao controle da doença. Sustentamos neste artigo que a pandemia causada pela covid-r 9 não é fenômeno puramente biomédico, mas eminentemente sociológico. Nesse sentido, também não é democrático, visto que as condições sociais, associadas aos aspectos territoriais marcados pelas desigualdades, são determinantes nas vulnerabilidades da população jovem.

\section{A COVID-19: DESIGUALDADES E VULNERABILIDADES}

Em 3I de dezembro de 20I9, a Organização Mundial de Saúde (OMS) foi informada pelo governo chinês da ocorrência de casos de um tipo peculiar de pneumonia em Wuhan, capital da província de Hubei. Essa cidade, que tem aproximadamente II milhões de habitantes, é um dos mais importantes centros industriais e tecnológicos do planeta. Também é um dos principais pontos de confluência logística e de transportes terrestres e aéreos do Leste Asiático. Tais características de Wuhan contribuíram para a rápida disseminação do vírus. No dia 7 de janeiro de 2020 foi confirmado que se tratava de um novo coronavírus, classificado por Sars-CoV-2, e pertencente ao mesmo grupo de vírus que já vinha causado epidemias anteriores de Sars (severe acute respiratory syndrome) e de Mers (Middle East respiratory syndrome). ${ }^{2}$ A nova doença foi chamada de covid-I9 (coronavirus disease 20I9). Quando Wuhan foi isolada, em 23 de janeiro, aproximadamente 5 milhões de pessoas já haviam se deslocado para outras cidades da China e do mundo. $\mathrm{O}$ primeiro caso no continente americano foi registrado em 2I de janeiro, nos EUA, por um homem que havia viajado a Wuhan. Já em 25 de janeiro se registravam os primeiros casos de covid-ı9 na Malásia e na Austrália. No mesmo período são registrados casos na Europa, que logo passaria a ser o principal centro de propagação internacional do vírus. Em 26 de fevereiro é registrado o

2 Em 2009-2010 aconteceu a primeira pandemia do século XXI, ocasionada pelo vírus Influenza A (H1N1), que resultou na morte de 100 mil a 400 mil pessoas no primeiro ano. 
primeiro caso na América Latina, de um brasileiro que havia retornado da Itália. Em março, todos os continentes, com exceção da Antártida, registravam casos da nova doença. Essa rápida propagação da doença em escala global leva a OMS declarar, em II de março, a covid-ı como uma pandemia planetária. Seu diretor-geral, Tedros Adhanom Ghebreyesus, na ocasião alertou: “Todos os países devem encontrar um bom equilíbrio entre proteger a saúde, minimizar problemas econômicos e sociais e respeitar os direitos humanos." (CORONAVÍRUS..., 2020)

No Brasil as primeiras mortes por covid-ı9 foram registradas em 17 de março, em São Paulo e Rio de Janeiro. As duas primeiras vítimas foram idosas, com doenças anteriores e que haviam viajado para o exterior. Em 2I de março já eram registrados casos em todos os estados brasileiros e no Distrito Federal. Em 24 de março o presidente da República, Jair Bolsonaro, em pronunciamento em rede nacional de rádio e televisão, conclama os brasileiros a não aderir ao isolamento preventivo e "voltar à normalidade"; pediu a plena abertura de estabelecimentos comerciais; classificou a covid-I9 de "gripezinha"; e disse que tudo não passava de "histeria" provocada por opositores. Passados 6 meses desse pronunciamento do presidente brasileiro, em Io de outubro de 2020 o número oficial de infecções desde o início da epidemia de coronavírus no país chegou a 5.082.637, e acumulavam-se I50.I98 óbitos oficialmente registrados em razão da covid-I9. Nesta data, São Paulo vinha sendo o estado brasileiro mais atingido pela epidemia, com I.034.816 casos e 37.223 mortes. A Bahia era o segundo estado brasileiro com maior número de casos, 324.964, seguida de Minas Gerais, com 32I.I4O. O Rio de Janeiro era o segundo estado com mais vítimas, somando I9.284 óbitos. Em seguida vinha o estado do Ceará, com 9.I30 vítimas fatais da covid-I9. A taxa de mortalidade por grupo de Ioo mil habitantes no Brasil era de 7I,5, uma das mais altas do mundo (BRASIL..., 2020). Frisamos que se trata de registros oficiais, porque o número real de infectados e mortos deve ser ainda maior, em razão da falta de testagem em larga escala e da subnotificação de casos.

Com o objetivo de tentar conter a rápida propagação do vírus, a OMS recomendou uma série de medidas de saúde pública e de higiene pessoal. Propôs medidas individuais como a lavagem frequente das mãos e o uso de álcool gel e de máscaras. Indicou também ações sociais como o distanciamento social, restrição à circulação e aglomeração de pessoas e a quarentena, ou isolamento durante certo período, para pessoas que tenham contato com pacientes contaminados, que estejam aguardando diagnóstico, que fiquem doentes ou que pertençam a grupos de risco. Recomendou também a adoção do chamado lockdown, que é uma medida imposta pelo poder público e que implica a interrupção de atividades econômicas e restrições à mobilidade (WHO, 2020).

A adoção dessas medidas restritivas às atividades econômicas colaborou para um cenário de agravamento da crise econômica mundial que já se estende desde 2008. No período de 2009 a 20I8, o aumento do PIB mundial foi de 2,5\%. Esse crescimento pífio só não foi pior devido ao crescimento econômico da China $(7,6 \%)$ e da 
Índia (7,I\%), em média, nesse período. Neste ano de 2020, segundo o Relatório do Banco Mundial de junho de 2020, a economia global sofre uma contração histórica de 5,2\%, levando a uma recessão acentuada em diversos países. Isso equivale à mais profunda depressão econômica em oito décadas. Como resultado, a expectativa de declínio para a renda per capita é de 3,6\%, o que levará milhões de pessoas à situação de pobreza extrema em 2020. Em um cenário mais negativo, essa instituição prevê uma retração da economia global de $8 \%$ neste ano, seguida de uma recuperação lenta em 202I, de apenas I\% (THE WORLD BANK, 2020).

A pandemia chegou ao Brasil com a economia semiparalisada. O Brasil viveu uma recessão entre 2015 e 2016 e entrou numa estagnação, apresentando um crescimento de I,I\% do PIB em 20I9. Segundo informações da Confederação Nacional da Indústria (CNI), a pandemia encontrou esse setor operando com capacidade produtiva já reduzida a $77 \%$, desde junho de 20I8, caindo para $76 \%$ em março deste ano, quando se inicia uma tendência de queda mais acentuada. A situação do mercado de trabalho, que já era ruim, ficou ainda pior. Krein e Borsari (2020) apresentam dados da Pesquisa Nacional por Amostra de Domicílios Contínua (Pnad Contínua) indicando que o ano de 2019 terminou com I6,2 milhões de desempregados ([desemprego] aberto e [por] desalento) e 6,7 milhões de subocupados por insuficiência de horas, além do forte peso do trabalho informal, 38,4 milhões de trabalhadores (subocupados inclusos neste contingente), quadro relativamente estável desde 2016.

Saboia, Baeta e Gomes (2020, p. 3) informam que o perfil médio do trabalhador desalentado - alguém que abandonou a busca por emprego por não acreditar que irá encontrá-lo - no Brasil, em 20I9, "era de uma pessoa responsável pelo domicílio, mulher, preta/parda, jovem, com ensino fundamental incompleto e vivendo na Região Nordeste”. De acordo com a Pnad Covid-ı,, entre março e maio 7,8 milhões de pessoas perderam seus empregos. Pela primeira vez na história, o nível de ocupação entre março e abril ficou abaixo de $50 \%$. Na semana de 6 a I2 de setembro, a taxa de desocupação registrada foi de $\mathrm{I} 4, \mathrm{I} \%$, atingindo $\mathrm{I} 3,9 \%$ na primeira quinzena 


\section{A pandemia de covid-19}

encontra a população brasileira

em situação de extrema

vulnerabilidade, com altas taxas

de desemprego, desmonte das

políticas sociais e intensos cortes

de investimentos em saúde, educação e pesquisa no Brasil

do mês e continuando o processo de elevação em relação aos meses anteriores: 10,7\% em maio, $12,4 \%$ em junho, $13,1 \%$ em julho e $13,6 \%$ em agosto (RAMOS; LAMEIRAS; CAVALCANTI, 2020). A Rede de Pesquisa Solidária da USP detectou que $75 \%$ da queda de horas trabalhadas no Brasil se devia à suspensão de contratos e à redução da jornada. Os outros $25 \%$ decorriam da inatividade. A renda média das famílias brasileiras caiu $\mathrm{R} \$ 250$, principalmente por conta da queda da renda do trabalho. Sem a renda básica emergencial, essa queda teria sido $40 \%$ maior ( $\mathrm{R}$ \$350); e se não houvesse o auxílio emergencial de $\mathrm{R} \$ 600$, a taxa de pobreza teria saltado para $30 \%$ da população (REDE DE PESQUISA SOLIDÁRIA, 2020).

As desigualdades sociais vêm se intensificando no Brasil. O coeficiente de Gini, que mede a concentração de renda, coloca o Brasil na Io ${ }^{a}$ posição entre os países mais desiguais do mundo, com índice mais elevado que países africanos. Nesse cenário de crise, em plena pandemia, a fortuna dos milionários brasileiros aumentou US\$ 34 bilhões (cerca de R $\$ 176$ bilhões). Conforme dados divulgados pela ONG Oxfam entre I8 de março e I2 de julho, o patrimônio dos 42 bilionários do Brasil passou de US\$ I23,I bilhões para US\$ 157,I bilhões. Por outro lado, a Fundação Getúlio Vargas (FGV) constatou que, no mesmo período, a renda média do brasileiro sofreu uma queda de 20,I\%: de R \$ I.II8 para $\mathrm{R} \$ 893$. Consequentemente, em plena pandemia a desigualdade social, medida pelo coeficiente de Gini, subiu $2,82 \%$ no Brasil.

A pandemia de covid-I9 encontra a população brasileira em situação de extrema vulnerabilidade, com altas taxas de desemprego, desmonte das políticas sociais e intensos cortes de investimentos em saúde, educação e pesquisa no Brasil. O Índice de Desenvolvimento Humano (IDH), que mensura o desenvolvimento dos países com base em aspectos como renda, saúde e educação, estabeleceu como nota brasileira, em 20I8, 0,539 - em uma escala de o a I, sendo I o nível mais alto possível (APESAR DE..., 2019). Esses dados indicam que a desigualdade social e o baixo desenvolvimen- 


\section{A condição juvenil}

\section{corresponde ao modo como a} sociedade posiciona os jovens em determinadas estruturas sociais. Mais do que uma faixa etária, a condição juvenil é uma posição nas hierarquias sociais

to humano influenciam a maneira como as pessoas vivenciam a situação atual, de tal modo que os riscos inerentes à pandemia são diferentes segundo a condição de cada classe social.

O sociólogo José Alcides Figueiredo Santos observa que a literatura especializada confirma os nexos causais da desigualdade socioeconômica na distribuição da saúde e da mortalidade das populações contemporâneas. Santos (2020) realizou estudos que confirmam a ocorrência de um tipo de "nexo invariante" - quanto pior a posição social, tanto pior a saúde — segundo o qual a posição socioeconômica estrutura ou influencia o grau de exposição aos principais fatores de risco e à progressão das doenças. Sua pesquisa mostra como no Brasil a estrutura social hierarquiza a distribuição da saúde (SANTOS, 2020). Na mesma linha, Pires, Carvalho e Xavier (2020) concluem que a população de mais baixa renda apresenta maior probabilidade de precisar de internação no caso de infecção pelo novo coronavírus, o que é agravado por outros fatores que tornam essas populações mais vulneráveis à crise de saúde pública e ao colapso econômico associados à atual pandemia.

Vulnerabilidade é um conceito que remete a situações em que pessoas, famílias e coletividades se encontram diante de riscos iminentes e ausência de direitos. Conforme a Organização Pan-Americana da Saúde (Opas), vários grupos permanecem com maior risco, particularmente aqueles "com acesso limitado à prevenção e cuidados", incluindo populações negras, hispânicas e nativo-americanas, que "têm quase três vezes maior probabilidade de entrar em contato com a covid-I9 do que as pessoas brancas" (OPAS BRASIL, 2020). Com efeito, na realidade brasileira podemos reconhecer nas populações das periferias urbanas das grandes cidades, das favelas e vilas irregulares, trabalhadores precarizados e na informalidade, pessoas em situação de rua, refugiados, indígenas, quilombolas, ribeirinhos assalariados rurais e outros que precisam 
lidar com a precariedade de condições materiais e com as desigualdades no acesso aos direitos os sujeitos mais vulneráveis diante da pandemia de covid-ı. Um estudo realizado por pesquisadores do Instituto de Estudos para Políticas de Saúde (Ieps) sobre a vulnerabilidade da população brasileira concluiu:

Em primeiro lugar, a incidência de fatores de risco entre indivíduos abaixo de 60 anos é elevada, principalmente entre aqueles de menor escolaridade. Segundo, além da maior vulnerabilidade de saúde, os indivíduos mais pobres também apresentam maior vulnerabilidade econômica. Terceiro, há uma grande sobreposição das vulnerabilidades de saúde e econômica entre indivíduos mais jovens e menos escolarizados. Quarto, há enorme desigualdade regional na incidência de vulnerabilidade de saúde e qualidade da infraestrutura de saúde para enfrentamento da pandemia. Mais ainda, há uma justaposição de maior vulnerabilidade e infraestrutura precária nos estados do Norte e Nordeste. Por fim, uma elevada parcela dos domicílios no país apresenta alta densidade habitacional e um elevado grau de vulnerabilidades econômica e de saúde (NUNES; ROCHA; ULYSSEA, 2020, p. 5).

O Brasil conta com uma população predominantemente jovem, com 42,3\% de toda a sua população composta por pessoas com menos de 30 anos de idade. Assim, entre as populações mais vulneráveis em relação à pandemia, temos um contingente expressivo de jovens. Conforme reportagem publicada pela agência Pública, em São Paulo, por exemplo, 93\% dos casos de mortes de crianças e adolescentes por síndrome respiratória aguda grave (Srag) comprovadamente relacionadas à covid-I9 ou sem motivo identificado foram de moradores de bairros periféricos ou de baixa renda. Ainda conforme essa reportagem, a condição racial também influi nos dados de internações e óbitos de crianças e adolescentes por Srag e covid-I9. Adolescentes e crianças de pele escura foram mais hospitalizados por Srag. Considerando a soma de pessoas de pele escura e parda, chegou-se a 7.I34 casos, enquanto os brancos representavam 6.27I das hospitalizações de menores de idade. As proporções de óbitos seguem igualmente diferentes entre brancos e não brancos. Foram 303 mortes de menores de idade pretos e pardos, contra 237 brancos da mesma faixa etária. Logo em seguida vêm as crianças indígenas, com I34 hospitalizações e I7 mortes, uma relação de I2\% de mortalidade. O critério "raça”, no entanto, foi marcado como "ignorado" ou mesmo não preenchido em 4.925 das hospitalizações e I89 dos óbitos (DOLCE, 2020). Esse quadro se intensificou com a reabertura gradual das atividades comerciais a partir de junho. Isso fez com que o perfil dos infectados mudasse, e os jovens passaram a ser a maioria. Segundo dados do Ministério da Saúde, I.037 jovens entre 20 e 29 anos relataram ter começado a sentir os sintomas da covid-I9 na semana do dia 7 de junho, número $28 \%$ maior do que o registrado na semana que teve início em io de maio (VÍRUS..., 2020). Com efeito, os jovens das classes populares inscrevem-se como a população mais vulnerável na pandemia de covid-I9 atualmente no Brasil. 


\section{CONDIĈ̣̃O JUVENIL E LIMITAÇ̃̃O DA MOBILIDADE}

A pandemia de covid-ı9 tem afetado os jovens brasileiros de diferentes maneiras. Entre outras coisas, resultou na necessidade de adoção de medidas de distanciamento físico e social visando à contenção do coronavírus. Essa situação tem impactado as formas de mobilidade no espaço social das cidades e, por consequência, as práticas de sociabilidade de todos os grupos sociais. Porém, em certa medida, os jovens foram os mais afetados. Isso porque eles vivem de forma muito intensa a sociabilidade entre pares de idade fora de casa, e houve o fechamento de espaços de concentração de pessoas, como bares, casas de shows e dança, parques, shopping centers, cinemas, todos esses considerados espaços de lazer e entretenimento e sociabilidade. Também foram fechados outros espaços, como os de formação, de educação e laborais. Emerge uma série de problemas relacionados à desigualdade social, expondo lógicas excludentes de acesso à cultura, ao trabalho, à educação, à moradia e à saúde, entre outras. Assim, são agravadas as dificuldades que caracterizam a condição juvenil, com efeitos objetivos e subjetivos entre os jovens, uma vez que o distanciamento físico tem gerado mais incertezas e dificuldades na relação espaço-tempo da vida dos jovens.

A condição juvenil corresponde ao modo como a sociedade posiciona os jovens em determinadas estruturas sociais. Mais do que uma faixa etária, a condição juvenil é uma posição nas hierarquias sociais (WEISHEIMER, 20I9). Os jovens tendem a ocupar uma posição social subalterna aos adultos, devido à relação de dependência e manutenção (FOARACCHI, 1965). Nesse sentido os pesquisadores da Organização das Nações Unidas para a Educação, a Ciência e a Cultura (Unesco) apontam cinco elementos cruciais da condição juvenil, que imprimiriam objetivos estratégicos em políticas públicas de juventude:

i) a obtenção da condição adulta, como uma meta; ii) a emancipação e a autonomia, como trajetória; iii) a construção de uma identidade própria, como questão central; iv) as relações entre gerações, como um marco básico para atingir tais propósitos; e v) as relações entre jovens para modelar identidades, ou seja, a interação entre pares como processo de socialização (UNESCO, 2004, p. 26).

Nesse sentido, argumentamos que a superação da subordinação e a conquista de autonomia constituem o eixo central da trajetória que os jovens deverão percorrer. Esse é um imperativo de toda a sociedade, intrínseco às dinâmicas das sucessões geracionais. Com efeito, assegurar aos jovens "oportunidades de autodesenvolvimento constitui meta social básica, processando da melhor maneira possível esse trânsito entre a infância e a condição adulta que todo jovem deve fazer" (UNESCO, 2004, p. 26).

A limitação da mobilidade ocasionada pela pandemia de covid-I9 interfere no processo de transição para a vida adulta, impedindo os jovens de forjarem seus 
próprios processos de fruição e busca por recursos que lhes assegurem a conquista de autonomia. Quando a pandemia chegou, mesmo uma boa parte dos maiores de 30 anos estava vivendo uma condição juvenil prolongada, como resultado de uma maior permanência no sistema educacional e da dificuldade de ingresso no mercado laboral. Com isso, a possibilidade de adquirir autonomia pessoal, que passa pela independência econômica, inclusive para ter o próprio lar e até constituir nova família, vai sendo cada vez mais adiada. Dando consequência à compreensão de que a juventude é um período de transição entre a condição de dependência na infância e a autonomia na vida adulta, observamos que a conquista dessa autonomia é cada vez mais difícil para a atual geração. E, para muitos jovens, pode jamais ocorrer.

Perante um futuro incerto, resta muitas vezes aos jovens buscarem viver intensamente o presente. Para muitos a única opção é enfrentar o que os adultos consideram como risco, o prezar ou a "sensação de adrenalina" em tal enfrentamento (ABRAMOVAY; CASTRO; WAISELFISZ, 20I5). Sem dúvida, esse processo de transições inviabilizadas é expressão das desigualdades sociais.

Os jovens engendram possibilidades de expressar formas de resistência e de enfrentamento em relação a essas situações adversas. Como nos lembra Pais (2016), eles e elas têm capacidade de construir utopias de vida; ao se constituírem em termos labirínticos, apresentam alternativas ambivalentes, discordâncias e futuros imponderáveis. Durante a pandemia, ganhar a vida, mesmo em condições sanitárias inadequadas; circulando em duas rodas, trabalhando como entregador; atravessando dias em frente de uma tela de computador ou celular; são formas possíveis de percorrer uma travessia incerta e também de alimentar esperanças possíveis de agenciamento e sociabilidade pós-pandemia.

\section{EDUCACÃO EM TEMPOS DE ISOLAMENTO SOCIAL}

A escola é considerada uma instituição privilegiada para a formação de crianças, adolescentes e jovens, para construir amizades e também para aprender. A escola é considerada um local privilegiado para aprendizagens, aquisição do saber (CHARLOT, 1997) e socialização dos sujeitos, levando em conta a diversidade dos indivíduos e grupos, evitando tornar-se um fator de exclusão social (DELORS, 200I, p. 54).

Um conjunto de reflexões de Morin (2000), para que se possa pensar a educação neste novo milênio, mostra como ela exige um desafio cognitivo, um esforço transdisciplinar para repensar os rumos que as instituições educacionais deverão assumir, devendo-se evitar a disciplinarização e a inércia. Ou seja, para o autor, há que repensar e reconfigurar a escola.

Conforme estimativa da Unesco, mais de I,5 bilhão de estudantes (mais de 90\%) pelo mundo estão confinados em casa por causa do fechamento de escolas em cerca de 190 países. A covid-I9 mostrou e aprofundou as desigualdades sociais existentes no Brasil e suas injustiças. O impacto da quarentena nas escolas, principalmen- 
te nas públicas, pode ser observado entre os estudantes de classes subalternas, que têm sido os mais prejudicados.

O fechamento de escolas públicas e privadas obrigou gestores, professores e famílias a improvisarem um modelo de educação para o qual o Brasil não estava preparado. O calendário escolar, em certa medida, tem sido mantido em algumas escolas de ensino básico e universidades, por meio da realização de aulas improvisadas em plataformas de videoconferência e ambientes virtuais de aprendizagem (AVAs).

Segundo dados de pesquisa do Instituto DataSenado 3 sobre a educação na pandemia divulgados em agosto de 2020, são quase 56 milhões de alunos matriculados na educação básica e superior no Brasil, sendo 35\% (I9,5 milhões) os que tiveram as aulas suspensas devido à pandemia de covid-I9, enquanto $58 \%(32,4$ milhões) passaram a ter aulas remotas. Na rede pública, $26 \%$ dos alunos que estão tendo aulas on-line não têm acesso à internet. Os dados ainda revelam que, na opinião de $63 \%$ dos responsáveis por alunos que tiveram aulas remotas, a qualidade do ensino diminuiu, e $75 \%$ das famílias cujos filhos tiveram aulas remotas nos últimos 30 dias preferiam que as aulas voltassem a ser presenciais somente quando a pandemia for controlada. Esses dados contribuem para evidenciar as desigualdades de diversas ordens, sejam tecnológicas ou econômicas, que impactam o ensino e a aprendizagem dos estudantes e geram consequências como o abandono e a evasão escolar.

Alguns dos problemas existentes têm relação com a falta de acesso à internet e de computador em casa. Outra questão apresentada são os limites tecnológicos, a falta de acessibilidade nas plataformas digitais para pessoas com deficiências e de espaço físico para assistir às aulas virtuais. Para a maioria, o acesso é feito exclusivamente pelo celular, que, além de pouca memória para o armazenamento dos conteúdos, apresenta limite de franquia de dados (planos-controle ou pré-pagos).

$\mathrm{Na}$ pesquisa que estamos realizando ficam visíveis as diferenças entre as escolas públicas e privadas no que tange ao tempo de aula, materiais disponíveis e acompanhamento dos professores. As características em comum giram em torno da dificuldade de aprender sem a presença física do professor e da falta de concentração (aparelhos ligados, presença de membros da família e dispersão nas redes sociais, entre outros inconvenientes).

Em um dos depoimentos, chama a atenção uma estudante de escola pública do ensino médio técnico em enfermagem, ao afirmar que nas aulas por meio de educação a distância (EaD )os alunos não têm aprendido nada:

- Eu abandonei por dois meses a aula on-line e voltei. Hoje continuo ficando alguns dias sem acessar as aulas que acontecem todos os dias, das $13 \mathrm{~h}$ às $\mathrm{I} 8 \mathrm{~h}$. Prefiro acumular e responder a tudo em um único dia porque todo o conteú-

3 A pesquisa do Instituto DataSenado foi realizada entre os dias 24 e 28 de julho. Foram entrevistados por telefone 2,4 mil brasileiros com 16 anos ou mais, em amostra representativa da população brasileira. Os resultados foram analisados considerando-se dois grupos: pais que têm filhos que frequentam escola ou faculdade e alunos de escolas ou faculdades (DATASENADO..., 2020). 
do e respostas estão nos sites como o UOL. Meus colegas também têm achado chato e alguns escolheram repetir de ano porque não estão aprendendo nada.

Outro estudante de escola particular do ensino médio declarou, sobre as suas dificuldades com o ensino remoto:

- O EaD não funciona. Só funciona para quem era muito focadão, quem só estudava, levava a sério e não saía, eu sempre saí depois das aulas para andar de skate. Estamos tendo aulas pelo Google Meet, e estou com saudades das professoras e das "irmãs" do colégio [católico].

Esta pandemia mostra a importância da escola, da socialização, do acolhimento e da oportunidade de revalorização da instituição, com maior reconhecimento dos professores, que é um fator de motivação para que os jovens não abandonem o estudo mesmo diante de adversidades (ABRAMOVAY; CASTRO; WAISELFISZ, 20I5).

As desigualdades entre estudantes de escolas públicas e privadas são evidentes nos depoimentos. Enquanto os de escolas públicas não têm contato direto com seus professores (as aulas acontecem na plataforma Google Classroom, que não permite interação, mas apenas o depósito de materiais), eles ainda têm uma sobrecarga com o trabalho doméstico, dispõem de menos espaço para estudar, mais responsabilidades, por cuidarem de algum membro da família (crianças, idosos), e menor possibilidade de acompanhamento por parte de pais ou responsáveis nos seus estudos, além de falta de estímulo para as atividades escolares. Os estudantes, apesar da saudade dos colegas e professores, da vida social e afetiva que lhes foi subtraída, temem pelo retorno, devido à precariedade de algumas unidades escolares, que não têm como atender aos protocolos de proteção e às exigências sanitárias.

Por outro lado, os estudantes das escolas particulares têm tido aulas diárias pela plataforma Google Meet, que possibilita o contato direto com os seus professores, e têm mantido a rotina anterior à pandemia, como aulas extracurriculares, sem interferências domésticas, com espaço e maior possibilidade de estudar. No entanto, também querem voltar à sua rotina presencial e encontrar tanto seus colegas quantos seus professores.

A pandemia mostrou o peso da importância da socialização e da escola, vista não mais como um local chato, de obrigação, sem interesse, mas sim como um lugar de possível proteção, onde os estudantes encontram amigos e professores de referência e poderão dar outro sentido ao espaço de aprendizagem, numa relação direta e cara com seus professores e seus pares. É sobre esse novo modelo de escola que temos de refletir conjuntamente.

\section{TRABALHO NO CONTEXTO DA PANDEMIA}

"Estamos vivendo tempos difíceis!" A nova organização flexível do trabalho aponta para a formação de um novo tipo de trabalhador, que tenha como requisitos 


\section{No $2^{\circ}$ trimestre de 2020,}

a taxa de desemprego da

população de 18 a 24 anos foi

de $29,7 \%$, enquanto a taxa de desemprego da população total ficou em 13,3\%

fundamentais a habilidade em transferir conhecimento de uma área para outra, facilidade em se comunicar e entender o que lhe está sendo comunicado, capacidade de trabalhar em grupo e com autonomia para a tomada de decisões.

Antunes (2020, p. 30), em suas análises sobre as transformações no âmbito do trabalho, afirma que "estamos vivenciando o crescimento exponencial do novo proletariado de serviços, uma variante global do que se pode denominar escravidão digital". As transformações que o "trabalho digital" impõe aos trabalhadores, que agora, em grande parte, passam a compor uma espécie de "infoproletariado" (ou "ciberproletariado") em todo o mundo, são transformações em curso, passando por temas como a expropriação do tempo de trabalho e de vida por empresas globais, a explosão do trabalho intermitente, as relações de gênero e classe, as novas formas de adoecimento dos trabalhadores, os desafios para a juventude que trabalha, o mito do "empreendedorismo", as greves e outras formas de luta da classe trabalhadora. Essa compreensão inicial permite refletir sobre os acontecimentos que estão presentes neste contexto de pandemia. As transformações no mundo do trabalho são permanentes e estavam presentes antes da pandemia.

A expansão da covid-I9 no Brasil tem provocado um efeito devastador no mercado de trabalho. Segundo dados da Pnad Covid-I9, o percentual de desempregados aumentou 20,9\% entre maio e julho desse ano. O país encerrou o mês de julho com I2,2 milhões de desempregados, cerca de 2,I milhões a mais que o registrado em maio. A taxa de desemprego passou de I2,4\% em junho para I3,1\% em julho. Segundo o levantamento, o número de trabalhadores ocupados teve queda de 3,5\% entre maio e julho, passando de 84,4 milhões para 8I,4 milhões. Ou seja, em três meses caiu em 2,9 milhões o número de pessoas ocupadas no mercado de trabalho (DESEMPREGO..., 2020). Esta tendência continuou no período de junho a agosto, com um aumento de I,4\% da taxa de desocupação em relação ao mês anterior, que passou a atingir $14,4 \%$ da população com mais de I4 anos em agosto. (IBGE, 2000a)

Os jovens são os mais afetados pelo desemprego, em especial os da classe menos favorecida, além de sofrerem os agravantes processos de discriminação de raça, gênero e etnia. Com uma taxa de 13,6\% em 20I9, o desemprego juvenil já era maior 
do que em qualquer outro grupo populacional. Pelo menos 2,67 milhões de jovens apareciam entre os chamados "nem-nem", ou seja, jovens que não conseguem nem emprego nem acesso ao ensino formal. No $2^{\circ}$ trimestre de 2020 , a taxa de desemprego da população de I8 a 24 anos foi de $29,7 \%$, enquanto a taxa de desemprego da população total ficou em $13,3 \%$ (IBGE, 2020b).

É um período que tem gerado muitas incertezas em relação ao que pode acontecer durante e após a pandemia de covid-I9. As entrevistas que realizamos com jovens entre 15 a 29 anos demonstram que aqueles que tinham trabalho e o deixaram por conta do isolamento social não sabem se, quando retornarem as atividades consideradas "normais", terão o emprego garantido. Outros, que só estudavam e tinham projeções para exercer uma profissão, com a suspensão das aulas não estão certos de que terão emprego após a conclusão do curso de nível superior, como expressam em algumas falas aqui inseridas.

Encontram-se jovens que estudavam e trabalhavam, e com o isolamento social deixaram de trabalhar, mas continuavam estudando na universidade pelo sistema de EaD. São jovens que moram na periferia da cidade, em condições de precarização tanto no aspecto de moradia como de renda familiar:

- Então, no momento eu estou parado, né? Tipo, eu trabalhava na Coordenadoria da Juventude e aconteceu que o Estado parou em algumas situações. Eu ia ser transferido e o Estado, como estava parado, não teve como eu ser transferido para outra secretaria, e eu fiquei à mercê dessa situação toda: passar para poder ser admitido novamente. (Entrevista realizada com estudante de graduação de $\mathrm{EaD}$ )

Alguns jovens têm expectativas e sonham em terminar o curso superior e trabalhar a fim de pagar o financiamento concedido pelo Fies ${ }^{4}$. Para os jovens que cursam faculdade privada e precisam pagar as despesas pendentes logo após o término do curso, o trabalho é essencial, tanto para o seu próprio sustento quanto para cumprir o contrato firmado com o referido programa, reafirmando-se o reconhecimento do trabalho nas sociedades contemporâneas. A inserção do jovem no trabalho faz parte dos processos de autonomia e reconhecimento coletivo ante as demandas impostas pelas relações sociais capitalistas.

Grande parte dessa população juvenil que precisa estudar e trabalhar vivencia um desejo de inserção social ao lado de uma perspectiva que dele distancia muitos que vivem em famílias com menores possibilidades de proporcionar as condições desejadas na atualidade, e o que se verifica é que neste período de isolamento social esses desejos se tornam desesperanças, como pode ser observado nessa passagem da entrevista realizada com com estudante de ensino superior, 23 anos:

4 O Fundo de Financiamento Estudantil (Fies) é um programa do Ministério da Educação (MEC), instituído pela lei $n^{\circ} 10.260$, de 12 de julho de 2001, que tem como objetivo conceder financiamento a estudantes em cursos superiores não gratuitos, com avaliação positiva nos processos conduzidos pelo MEC e ofertados por instituições de educação superior não gratuitas aderentes ao programa. 
- Queria terminar o curso e começar a trabalhar. Ganhar meu dinheiro. Meu estágio foi suspenso, a Defensoria não está funcionando. A pandemia veio e atrapalhou todos os meus sonhos. Não consigo estudar, não consigo me concentrar, não tenho emprego. A pessoa tem vontade de estudar porque se está abrindo concurso, né? Abro os sites de concurso e não vejo uma previsão de edital. Não tenho motivação nenhuma.

As jovens mulheres têm sido afetadas; quando são provedoras da família, saem para trabalhar fazendo bicos, "vendendo coisas", levando os filhos com o fim de garantir o sustento deles. Como expressa esta outra entrevistada:

- Eu tenho amigas que têm filho pequeno, da idade da minha filha, que estão se colocando em risco, estão vendendo coisas, e estão saindo com os próprios filhos, porque precisam sobreviver, precisam comer e pagar as contas. Todo mês tem conta de água, de luz, tem que comer todo dia, tem que fazer alguma coisa...

Essas e outras situações são encontradas na realidade dos jovens. São aproximações, pelos depoimentos e dados apresentados nesse período de realização do estudo, que ainda carecem de aprofundamento e de apreensão de outras condições vivenciadas por eles, para que se possam fazer afirmações mais generalizadas.

Encontram-se nesses contextos de pandemia jovens que pensam o trabalho como experiências ou modo de vida, fora do emprego formal, associando atividades laborais no campo das diferentes culturas e práticas de espiritualidade que, na compreensão dos que se distanciam do trabalho formal e informal, tanto podem beneficiar a vida em particular como a vida em coletividade, compreendendo-as como ações que propiciam o desenvolvimento humanitário mais abrangente e global.

\section{RESISTÊNCIA E EXISTENNCIA DURANTE A PANDEMIA}

Ouvir os jovens na pesquisa sobre suas trajetórias e a pandemia no Brasil alçou os entrevistadores a uma função de depositários de sonhos para restituir lugares sociais. E, por vezes, para constituir bordas, no sentido lacaniano, para um vazio diante de uma pulsão de morte, esta entendida como algo que impõe desligamentos, como os promovidos pela pandemia e todos os seus protocolos de distanciamento físico e social. Apresenta-se a recuperação da palavra, da memória e da história como algo que inscreve, liga a uma espécie de devir, um vir a ser aqui e agora, que é pulsão de vida, entendida aqui como o que possibilita ligamentos.

Perante a escuta do seu desamparo e do desejo de continuar existindo e superar formas de inexistir, na ausência de escola, de trabalho, de encontro de corpos e experiências, os jovens relatam uma necessidade de dar a ver, de dar à luz para não serem invisibilizados, ocultados de si mesmos. $\mathrm{O}$ advento da pandemia e todos os protocolos de segurança levam, invariavelmente, parte significativa dos e das jovens 
a um refúgio na ilusão. Ilusão, para Freud (1996), é derivada do desejo, os desejos são a realidade das ilusões, o desejo de negar o desamparo. Assim, um refúgio na ilusão pode funcionar como estratégia de fuga da realidade.

Deparamo-nos com jovens constituídos de marcas individuais e sociais, de esperança na acolhida da família, e, outros, vítimas do preconceito e da dor pela ausência de família e de referências, desde antes da pandemia, para se refugiarem. Entretanto, as marcas são emissárias de boas notícias, no sentido de um não apagamento das trajetórias juvenis. Marcas em que testemunhamos a existência, na forma de narrativa de experiências, no sentido atribuído por Benjamin (1987), de experiências comunicáveis vinculadas à arte de contar, que deixam rastros de dores ou de alegrias, mas presenças comunicáveis.

Os jovens pesquisados existem e resistem, numa insistência em existir se expressando em narrativas que imprimem sentidos aos impeditivos da pandemia e à aproximação com a incerteza, com os riscos, inclusive da morte, agudizando a ambivalência da condição juvenil atual. O sociólogo Português José Machado Pais destaca: Jorge Luis Borges, como se sabe, era um cultivador de labirintos. O labirinto é uma das muitas figuras do caos, entendido como uma complexidade cuja ordem existe, embora de forma oculta. Por isso, os labirintos, enquanto estrutura de uma globalidade, são realidades complexas, porque não é fácil encontrar a porta de saída dessa globalidade. O que observamos nessa complexidade, por um lado o prazer do extravio; por outro lado a expectativa de se sair do labirinto com as astúcias da razão (ou do sentido) [...;] embora para alguns jovens os riscos ofereçam oportunidades e sejam aceites na expectativa de benefícios [...,] para muitos outros jovens a vida é como uma loteria [...;] os riscos ameaçam, mas é a insegurança que verdadeiramente torna a vida insegura [...; o que constatamos é que os jovens, por se sentirem num labirinto de vida, tendem muitas vezes a negar a vigência da realidade através das margens para as quais são frequentemente relegados [...;] nos labirintos da vida alguns jovens acham-se depois de se perderem (PAIS, 20I6, p. 54).

As pandemias impõem novas dificuldades à própria condição transitória e liminar da juventude, congelando a vida juvenil pela subtração da escola, do trabalho. Para muitos jovens adultos, isso implicou o retorno à casa dos pais. Para todos, agravou a descontinuidade da vida sem fixação, os eventos imponderáveis em que vidas cruzam existências sociais, subjetivas e emocionais, como nos aponta o pensamento de Pais. Nesse exato aspecto do imponderável da experiência pandêmica emerge, para muitos desses jovens, de variadas classes sociais, gêneros, raças e escolaridades, um olhar diferenciado na forma de perceber e viver a vida, que os mobiliza pelo afeto, como campo da experiência, como manifestação das interações humanas.

Observamos em muitos desses jovens o despertar de repertórios simbólicos de sobrevivência subjetiva, na busca de equilíbrio psicossocial para reconstrução do que desmorona. As redes de afeto dos jovens gregários, que se veem sem alternativas 


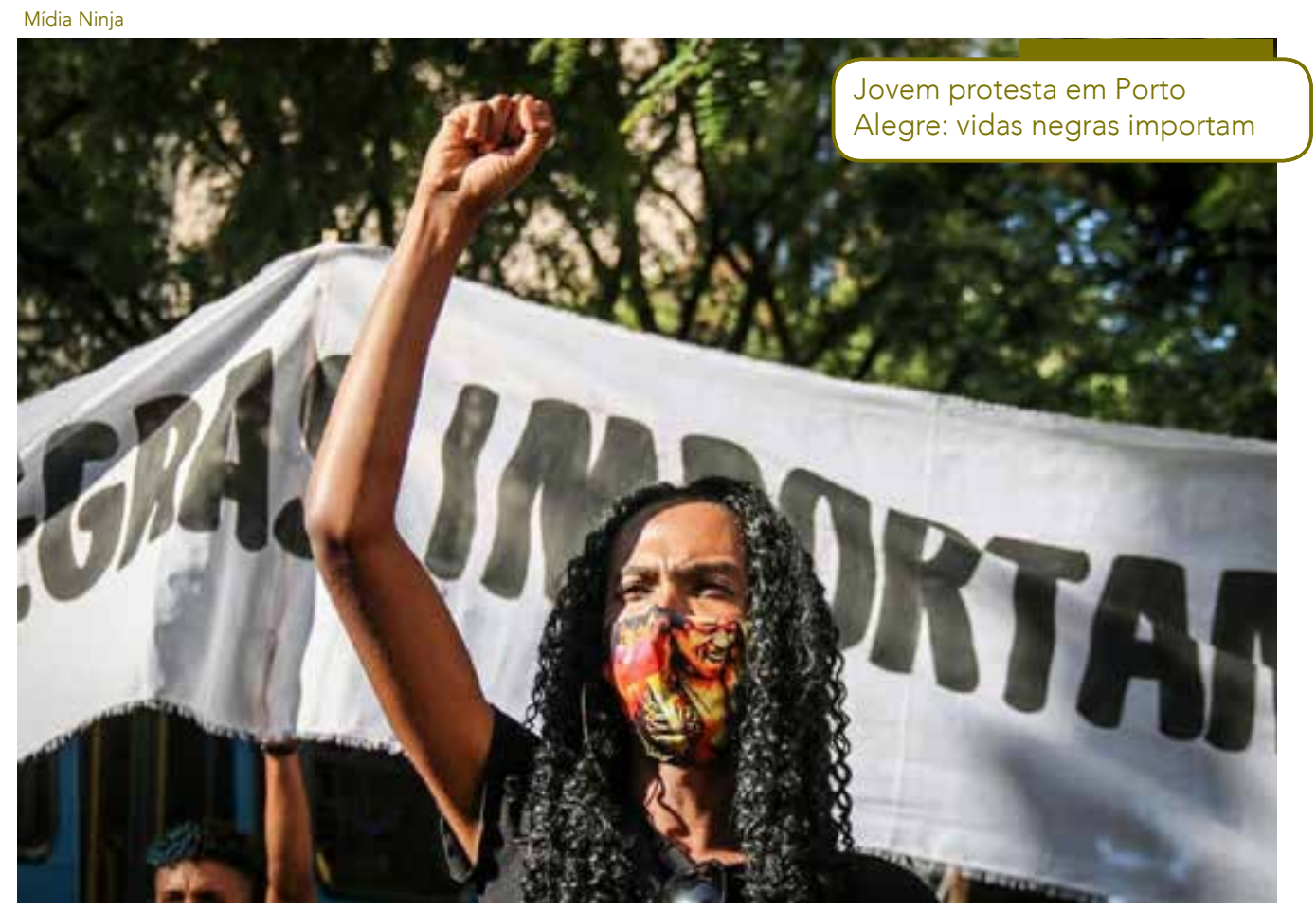

agenciadas de produção do comum, se valem de novos arranjos de afetividade, na experiência estética pela arte, como forma de ampliar a potência afetiva. Afeto que, para Deleuze (2002), é da ordem do sensível, sem narrativa lógica, ganha potência pela arte, como uma afetação que rompe com os dispositivos do poder estatal sanitário, de distanciamento e isolamento, que a pandemia inscreve como dispositivo de subjetivação. Arte no sentido de criadora de sensações e experiências no encontro com o inesperado, o acaso para a produção de afetos. Afeto como a transição de um estado a outro, transição boa ou ruim, definida pelo aumento ou diminuição da potência do corpo ao agir. Com o cenário de afecção suprimida pelo não encontro de corpos na interação com seus pares, os jovens veem dificultada a transição de afetos, interferindo na potência do agir e variando a potência do existir.

Testemunhamos nas narrativas de muitos jovens algo de inventivo envolvendo afetos, imaginação e percepção. Nossa hipótese é que parte expressiva desses jovens trabalham a estética dos afetos por meio de manifestações criativas e artísticas, tendo nessas múltiplas expressões de arte um modo de produzirem signos que modificam a estética de suas existências na pandemia e para além dela. Destacamos três relatos de jovens em suas descobertas durante a reclusão na pandemia. Memórias de suas histórias, conexões com suas habilidades, inventividades e defesas.

Trazemos o depoimento de uma jovem de I6 anos, estudante secundarista de uma escola técnica no estado de São Paulo:

- A cada dia nos jornais a gente vê pessoas retintas morrendo simplesmente pela cor. Eu temo pelo meu irmão na rua. Hoje o meu cabelo é um sinal de 
liberdade e autoaceitação. Por muito tempo eu passava chapinha no cabelo e não suportava meu cabelo por simplesmente não ver ele em lugar algum... Fui reconhecendo minha beleza e hoje meu cabelo é um sinal de poder. Eu retrato, nessa pandemia, justamente o que queria ver e por muito tempo não vi. E o movimento "Vidas negras importam" foi só um retrato do que há muito tempo vinha acontecendo, e me senti bem confortável por ver que as pessoas ainda lutam pelo que acreditam.

Nesse momento a jovem entrevistada recita um poema de sua autoria em que retrata o que descreveu como "autoconhecimento adquirido na pandemia":

- "Mil e uma versões./ Me vi em mil e uma versões,/ Cada uma com suas diferenças./ Entre o isolamento me reconheci,/ Pensando até ter me multiplicado./ De todas as coisas ruins,/ Sempre surge um aprendizado./ Será que a hora da evolução/ Chegou em forma de tornado? / Nada é de todo ruim,/ Assim como nada é de todo bom./ Durante a quarentena passei mil e uma situações/ E todas fazem parte das minhas mil e uma novas versões.”

Já de uma jovem de I9 anos, estudante universitária na USP, ouvimos:

- O que mais me marcou na pandemia foi o voltar-se para si. Tudo o que tenho em textos são reflexões que surgiram em razão dessa mudança. A comida me reinventando na cozinha e equilibrando o stress. Conectada com o mundo. As meninas estupradas, minha vida alargada e poetizada.

E ela recita:

- "O homem do saco preto": Angélica nunca imaginaria! Na candidez de sua décima primavera, sem nenhuma licença, muito menos bença, abrem seus botões. Nem fogo nem navalha não temia. Flagrante que só, porém, era o medo que mamãe compartia: o homem-escuridão, aquele que carrega o saco na mão. Coitada de mãinha! Não sabia. Até o podre do chorume dissipa-se no sereno perfume. E a noite? Cala."

Identificamos nos depoimentos a arte como ampliação da potência afetiva, deslocando o olhar para a experiência estética que confere mobilidade inventiva na percepção da vida desses jovens. Uma aliança com a potência do agir, inaugurando existências em campo social árido, diante de políticas governamentais negacionistas, de sofrimento e risco, de descompromisso com a saúde, com a ciência, desidratando a educação, os direitos constitucionais, aprofundando preconceitos e intolerâncias, asfixiando a cultura e a expressão mais criativa e livre de uma população. Os jovens engendram resistências objetivas e subjetivas, se fortalecem e emprestam a experiência comunicável que as políticas públicas voltadas às juventudes poderão alimentar. 


\section{AS PERCEPCÕ̃ES DOS JOVENS SOBRE O FUTURO PÓS-COVID-19}

No prefácio ao livro Notas sobre a pandemia: e breves lições para o mundo pós-coronavírus, o historiador israelense Yuval Noah Harari adverte: "Haverá tempo suficiente no futuro para escrever esta história. Agora não é momento de escrevê-la, mas de fazê-la" (HARARI, 2020, p. 7). Como esse autor, na investigação em tela não temos a pretensão de esgotar todas as conjecturas sobre o que os jovens acreditam que será o futuro pós-pandemia, mas de apresentar uma interpretação sobre narrativas recolhidas dos diálogos realizados. Intentamos alargar o conhecimento sobre o discurso de jovens acerca do futuro pós-pandemia e contribuir para políticas públicas juvenis que efetivamente contemplem suas demandas.

As expectativas de jovens para o futuro pós-pandemia apontam para perspectivas que são pautadas em dilemas da encruzilhada histórica provocada pela covid-I9. Estudiosos como Harari (2020), Grimson (ARGENTINA UNIDA, 2020) e Segato (2020) afirmam estar em ação não somente uma crise de saúde, mas os caminhos e descaminhos da crise sanitária e política que resulta numa grande crise de dimensões global e local. Tais impactos ressoam na vida desses jovens, sejam eles econômicos, psicológicos, materiais e subjetivos.

As narrativas juvenis neste estudo, obviamente, não se apresentam de forma homogênea, parecem estar intrinsecamente relacionadas ao lugar social ocupado pelos sujeitos. Elas revelam perspectivas negativas relacionadas aos impasses crescentes para efetivarem seus projetos de escolarização, de profissão e de vida, que completariam suas trajetórias sociais em busca de autonomia. Os argumentos de desesperança aparecem, também, relacionados às posturas políticas dos gestores, no que se refere ao enfrentamento da pandemia de covid-I9, com destaque para as deliberações relativas aos serviços públicos, notadamente de saúde e educação. Os depoentes demonstram ainda preocupações e indignações quanto às oportunidades de ingresso ou permanência no mercado de trabalho como questão central, bem como quanto ao risco de violência policial, de racismo e de preconceito contra relações não heterossexuais.

Entre jovens com idades maiores dentro do universo desta pesquisa, compreendidas entre 2I e 29 anos, percebemos que eles veem que seus estudos e projetos profissionais foram comprometidos. Há em seus depoimentos um descrédito e uma baixa confiança na governabilidade e na democracia, um descontentamento com os rumos do Brasil e com as perspectivas de um "novo normal". Percebemos em suas falas a disposição para ações coletivas expressa em manifestações de desejo de "fazer a diferença", de realizar ações que provoquem mudanças na sociedade brasileira. Emerge um potencial de transformação social vinculado a valores como a defesa da vida e a busca de uma sociedade mais democrática, igualitária e que proporcione verdadeira igualdade de oportunidades e melhor qualidade de vida. Emerge assim uma ambivalência, visto que os jovens mais descontentes e com perspectivas mais 
pessimistas são os mesmos que evocam a necessidade de transformações profundas no país. Porém eles não vislumbram alternativas reais para essa construção, ficando ainda no campo dos sonhos e esperanças incertas.

Vejam-se as palavras desta jovem de 29 anos, graduada em Comunicação Social e em Ciências Sociais, negra, de classe média baixa e heterossexual:

- Eu sonho com um futuro em que as pessoas negras, jovens, sejam visíveis, pois estão em uma condição mais invisível. Porque todas as políticas públicas de que a gente tem ouvido falar estão voltadas para o jovem branco e mais ou menos de classe média. E não vão contemplar a pessoa negra, periférica, ou que já tenha outros problemas. Então, a gente precisa pensar nessas nuanças, porque as pessoas negras ainda estão aprendendo a escrever, ainda estão tentando ocupar espaços de poder. Muitos jovens negros ainda estão naquele lugar visualizado, na violência. Eu acho que comprometeu muito, embora a gente tenha visto muita gente boa, negra, produzindo conteúdo, a massa ainda está referenciada muito na violência.

Um jovem de 28 anos, com pós-graduação em administração de empresas, branco, de classe média e heterossexual acredita que

se a gente vai ter uma melhora significativa que tanto espera, eu não sei. $\mathrm{E}$ a gente espera que [este] seja um país, um dia, de Primeiro Mundo. Eu não sei, a cultura do país impede muito isso, é uma cultura em que as pessoas pensam muito em si. Principalmente na política, né?

Estamos diante do que os estudos de gênero denominam de marcadores sociais da diferença, como bem demonstram os estudos sobre interseccionalidade. Como afirma Brah edo grave

A análise das interconexões entre racismo, classe, gênero, sexualidade ou qualquer outro marcador de "diferença" deve levar em conta a posição dos diferentes racismos entre si. Acima de tudo sublinho a importância de uma microanálise que estude as inter-relações de várias formas de diferenciação social, empírica e historicamente, mas sem necessariamente derivar todas elas de uma só instância determinante.

Registramos também jovens de faixa etária menor que 2I anos, dentro do universo pesquisado, que se ancoram em argumentos de esperança. Eles veem a crise pandêmica como oportunidade de mudar as orientações do Brasil e do mundo; de ajudar a humanidade a enxergar e rever sua postura diante das mazelas das desigualdades sociais, violências, discriminações e ameaças à democracia e do grave perigo que a falta de compaixão, de solidariedade, de gratidão, de relação, de não parceria com a natureza representa. 


\section{A incerteza quanto ao futuro se inscreve como marca indelével da atual geração juvenil. A crise multidimensional que afeta a sociedade brasileira, agravada pela pandemia, turva o horizonte e inibe os jovens na construção de projetos ajustados a seu campo de possibilidades}

Uma jovem de 20 anos, negra, graduanda em Ciências Sociais, de classe média, afirma:

- Eu quero muito conseguir terminar o meu Pibic e o meu curso, e daqui a 5 anos estar no doutorado. Quero me formar em 202I, fazer mestrado e doutorado. Quero também trabalhar, prestar assessoria, elaborar projetos. Tenho esperanças de que tudo vai dar certo.

Um jovem de 17 anos, negro, estudante do ensino médio, de classe baixa, compartilha sua expectativa quanto aos estudos e a vida profissional no futuro:

- Quero fazer o curso de computação. Eu quero passar num concurso. Acho que vou conseguir com o meu estudo ter um futuro melhor.

Outra jovem de 2I anos, graduanda em Ciências Sociais, negra, de classe média, heterossexual e sem religião, mas espiritualizada e frequentadora de espaços religiosos que consagram a ayahuasca, revela que, mesmo diante do medo da morte, ainda tem a esperança de realizar seus projetos, sonha em concluir a pesquisa de iniciação científica em andamento e deseja que até o fim do ano seja encontrada uma vacina que traga a cura da covid-I9:

- Eu não quero chegar a dezembro e a gente ainda estar vivendo isso. Outro sonho para o meu futuro é sair viva; os meus familiares, meus amigos, se forem contaminados, que consigam sobreviver.

Outra jovem, de I8 anos, negra, graduanda em Arqueologia e umbandista, nos narra suas expectativas para o futuro pós-pandemia:

- Creio eu que vai ser um futuro em que as pessoas terão o dever de se higie- 
nizar, as pessoas vão aprender o verdadeiro significado disso e aprender a ser mais solidárias com o próximo. Até na questão dos estudos acredito que haverá muitas melhorias; quando as aulas se retomarem, podem se acertar entre aulas remotas e presenciais.

Essa esperança de um futuro promissor, expresso no início da pandemia por jovens adolescentes que acreditavam que haveria maior solidariedade no decorrer do tempo, foi se alterando. O pessimismo com relação ao futuro do país é o que mais se salientou. Conforme as palavras de um jovem de I8 anos, estudante, morador da cidade de São Paulo:

- Eu não vejo que o país vai mudar, acho que vai piorar. Não acho que existe preocupação com os outros. Agora cada um pensa em si. Um monte de amigos indo para festas [...] e não estão nem aí [...,] pensando só em si.

Outra jovem, de 22 anos, desempregada, também de São Paulo, comenta:

- No início da pandemia fiquei preocupada, pois estava desempregada. Agora estou desesperada. [...] Também vários dos meus amigos perderam o emprego. [...] Não sei como será o meu futuro, principalmente porque vejo um futuro muito ruim ainda no país.

Uma jovem de 2I anos, estudante universitária de História, também relata sua preocupação:

- suscitam Posso dizer que meus amigos estão muito desanimados, e olha que eu estudo na USP! Estamos estudando, mas ninguém sabe se teremos emprego.

Como em todos os temas, as perspectivas de futuro das juventudes também apareceram com marcas de classe social. Enquanto aqueles de classe média e alta projetam um futuro de estudo, com perspectiva de cursar uma graduação e pós-graduação, acreditando que logo poderão trabalhar em suas áreas, as juventudes das classes subalternas demonstram medo de não dar continuidade aos seus estudos. Diante dessa realidade, inserem-se em trabalhos precários, sem garantias, e falta de perspectiva em relação ao futuro.

A incerteza quanto ao futuro se inscreve como marca indelével da atual geração juvenil. A crise multidimensional que afeta a sociedade brasileira, agravada pela pandemia, turva o horizonte e inibe os jovens na construção de projetos ajustados a seu campo de possibilidades. A transição para a vida adulta, no quadro histórico atual, revela-se uma realidade de riscos e incertezas. Nesse contexto, os jovens recorrem a um refúgio no presente. Sendo o futuro tão incerto, se apresenta mais como sonhos e desejos do que como projeto efetivo capaz de orientar a ação. Essas manifestações podem ser interpretadas mais como um desejo de no futuro viver em uma sociedade 
melhor, sem se converterem necessariamente em formas de ação social orientadas para essa construção. Com efeito, as representações dos jovens sobre o futuro trazem uma consciência discursiva cuja força intrínseca revela as contradições do presente, que oscila entre esperanças e desencantos.

\section{CONSIDERACÕES FINAIS}

A tarefa de iniciar uma reflexão sob uma perspectiva multidisciplinar das trajetórias de jovens em tempos de pandemia é um desafio que tentamos alinhavar por meio de diferentes olhares e percepções. Para conhecer trajetórias e práticas juvenis em tempos de covid-ı9 pela interface da condição juvenil, de sua socialização, sociabilidade, subjetividade, distanciamento social e práticas cotidianas, optou-se por seguir as tramas presentes nos discursos das e dos jovens entrevistados. Buscamos assim reconstruir os sentidos atribuídos por brasileiros, em distintas situações juvenis, aos impactos da pandemia de covid-I9, tanto sobre as suas práticas cotidianas quanto sobre suas trajetórias de transição à vida adulta, que marcam a condição juvenil. Etapa em que a perplexidade e a ambivalência alternam dúvida e construção de convicções, suscitam momentos de desequilíbrio e descontentamento, quando o desejo de experimentar o novo está acompanhado por incertezas, pela avidez de conhecimentos, pelo espanto e as indefinições cotidianas de uma realidade que, simultaneamente, atrai e atemoriza.

Apresentar as práticas juvenis desenvolvidas durante o período de distanciamento social no que se refere à educação e ao trabalho explicitou o quanto se aprofundou a desigualdade social que permeia o Brasil, um dos países mais desiguais do mundo. Desigualdade que é acompanhada de forte imobilidade social sistêmica, em que parte da população se torna uma massa "inempregável" de "subcidadãos". Os depoimentos obtidos sobre a relação desses jovens com a escola e o trabalho apontam para o declínio abrupto de dispositivos de integração social e o colapso de um incipiente e precário modelo de proteção social e suas formas institucionais, como no fechamento das escolas e na redução da capacidade de oferta de emprego, ao mesmo tempo que se aprimoram os processos de desregulação do trabalho e sua consequente precarização. Esses fatores indicam um cenário social com imensos desafios, uma vez que se intensificam a concentração de oportunidades de uma vida saudável e de bens socialmente valorizados, de um lado, e a precarização da vida, a produção de uma miserabilidade estrutural, a marginalização de indivíduos e a desestruturação de laços comunitários, de outro.

Contudo, são esses laços comunitários e os processos de socialização dos jovens que foram especialmente afetados. A educação escolar, como instituição principal do processo de socialização secundária, teve de ser reestruturada, não mais como espaço de socialização, mas como transmissora de conteúdos veiculados pela tecnologia. Nessa perspectiva, a função social da escola se esvai e se transforma, mes- 
mo para aqueles que têm condições objetivas de acompanhar as aulas. No entanto, é importante reforçar que tal situação é extremamente agravada para aqueles, vulnerabilizados pela sociedade, que não têm acesso a nenhuma proteção social. Pode-se desvelar como as políticas públicas de educação não fazem parte de uma agenda mínima de garantia de direitos, o que implica um círculo vicioso em que o abismo da desigualdade social se intensifica cada vez mais. A responsabilização de estudantes e suas famílias pelo mau desempenho escolar tem demonstrado o quanto estamos inseridos na lógica individualista e culpabilizante, que reitera a dificuldade da construção e fortalecimento de laços sociais, explicitando que a dimensão do outro, na perspectiva de uma vida em comunidade e dos propósitos humanos, se deteriora no conjunto da vida social. Tudo isso reforçado, como já apontamos anteriormente, por uma desigualdade social que implica desde a falta de instrumentos para assistir às aulas (tecnologia) até o espaço físico para que isso ocorra de uma forma minimamente adequada.

No que se refere ao trabalho, ou melhor, à falta e ainda à precarização do trabalho, constitui-se em questão crucial para compreender a situação das classes subalternizadas. Percebe-se a diferença de perspectivas de trabalho, ou até de significados do trabalho, entre os jovens que têm a subsistência garantida pelos familiares e aqueles que dependem da sua própria força de trabalho para garantir a subsistência dos familiares. A lógica se inverte: o significado da proteção e sobrevivência para os primeiros é permanecer em casa, para garantir a sua saúde e dos mais próximos; já para os outros, sair de casa e "interromper a quarentena" é um imperativo para a sobrevivência, sua e da família. Na realidade, por mais distantes que esses grupos parecem estar um do outro, existe um fio condutor que os une, considerando-se que foi o trabalho de muitos jovens das classes empobrecidas pelas relações sociais capitalistas que possibilita aos primeiros permanecerem em suas casas durante a quarentena. Novamente, a desigualdade social, as humilhações, a dificuldade de perceber o outro como um igual, como um sujeito, vão cada vez mais esvanecendo o que resta de solidariedade social. No entanto, no campo das percepções juvenis, os jovens que se encontram nas duas situações têm em comum a insegurança em relação a sua inserção no mundo do trabalho. As condições socioeconômicas delimitam essas trajetórias, e esses jovens buscam estabelecer estratégias para o cuidar de si e do outro em relação à covid-I9. Um cenário que resignifica a ideia de que os e as jovens são os menos afetados por esta situação. Em vez disso, os jovens surgem como categoria propícia para simbolizar os dilemas contemporâneos, catalisam as tensões sociais como também as exteriorizam, tornando-se vitrine de conflitos sociais.

A limitação da mobilidade ocasionada pela impossibilidade de transitar pela cidade interfere na autonomia juvenil para forjar seus processos de fruição como forma de se expressar nos próprios territórios, mas também estabelece condições objetivas e subjetivas que impedem muitos jovens de praticar o distanciamento físico e social. Do ponto de vista objetivo há grande desigualdade de condições de moradia, 
de trabalho, de renda, de estudo e de acesso à internet e a equipamentos adequados para conectividade.

Assim, a contradição entre um discurso e algumas práticas de solidariedade direcionados aos mais vulnerabilizados — iniciativas, na sua maioria, da sociedade civil - e a realidade vivida por todos, especialmente pelos e pelas jovens, produziu em larga escala um sentimento de desânimo pela falta de perspectivas. No entanto, a pluralidade de entrevistados nos possibilita verificar que para alguns desses jovens existe uma esperança de um mundo melhor. A trajetória desses jovens apresenta-se como um desafio a ser ultrapassado, ou simplesmente vivido. Podem-se perceber formas de resistência, de criatividade em lidar com o tempo, em resignificar a sua história, as suas práticas, como pudemos apresentar nos exemplos de resistências. Experiências que demonstram as brechas encontradas para sobreviver em um terreno tão hostil. Experiências que nos dão pistas e possibilidades para refletir sobre as juventudes e as perspectivas da construção, com eles, de alternativas para a resistência individual e coletiva.

A pesquisa em andamento tem nos propiciado inquietações teóricas e práticas. Por se tratar de uma escuta que busca alcançar as nuanças de diferentes âmbitos do processo juvenil - psicológico, interpessoal e social - que afetam as trajetórias desses e dessas jovens, apontam para certezas e incertezas, verdades e contradições, formas de resistência e existência. Que trazem à tona possibilidades de uma reflexão do particular para o universal, e vice-versa, estando aí a especificidade desta pesquisa em andamento.

Nesse sentido, contextualizar onde essas experiências ocorrem e os sentidos atribuídos a elas por jovens brasileiros é essencial para que possamos enfrentá-las, não só como uma questão individual, ou intrínseca a cada jovem entrevistado, mas numa perspectiva coletiva, como desafio para um projeto de nação e civilização. Estando cientes de que o acirramento das desigualdades sociais, o desmonte de políticas públicas, a corrosão das formas de solidariedade social e a negação de grupos sociais como sujeito de direitos têm consequências como o recrudescimento das saídas antidemocráticas, intensificando a reprodução social das desigualdades e a crescente política de criminalização das parcelas mais pobres da população brasileira, em especial os jovens e não brancos.

São trajetórias singulares, que em comum carregam as marcas da desigualdade social, inscritas pela classe, gênero e cor de pele. Essa condição social subalterna e precarizada vai produzindo os sentidos possíveis para a vida de cada um deles. Enquanto para alguns a covid-I9 originou uma reflexão sobre as formas de sobrevivência à doença, para outros jovens essas preocupações sempre estiveram presentes, e hoje seu grande desafio é existir e poder viver, isto é, resistir.

Assim, diferentemente do discurso hegemônico segundo o qual os jovens correm menos riscos na pandemia de covid-I9, as inferências empíricas obtidas demonstram que os jovens estão em situação bastante vulnerável. Eles sentem de múltiplas 
maneiras, de modo objetivo e subjetivo, os impactos da pandemia em suas trajetórias sociais e práticas cotidianas. Ficará a sociedade brasileira indiferente a essa situação que põe em risco toda uma geração? A construção social de alternativas passa por tornar visível a vulnerabilidade social em diferentes situações juvenis. Este trabalho se propôs a dar uma contribuição inicial a esse debate, que, acreditamos, precisa ser aprofundado.

* Doutora em Serviço Social pela Pontifícia Universidade Católica de São Paulo (PUCSP). Pós-doutora em Sociologia pela Universidad Nacional Autónoma de México. Professora associada III da Universidade Federal do Piauí (UFPI). Professora do Programa de Pós-Graduação em Sociologia da UFPI. Coordenadora do Núcleo de Pesquisa sobre Crianças, Adolescentes e Jovens (Nupec). Atualmente desenvolve pesquisa sobre juventudes e desigualdade social, gênero e mercado de trabalho e demandas profissionais.

** Doutora em Psicologia Escolar e do Desenvolvimento Humano pela Universidade de São Paulo (USP). Pós-doutora em Pesquisaem Ciências Sociais, Infância e Juventude pelo Conselho Latino-Americano de Ciências Sociais (Clacso). Atualmente é pesquisadora do Instituto de Saúde da SES-SP e da Faculdade Latino-Americana de Sociologia (Flacso-Brasil), Coordenadora do grupo de trabalho Infância e Juventude: Políticas, Culturas e Instituições Sociais, da Clacso. Membro/pesquisadora do Nupec. Pesquisadora/colaboradora no grupo de pesquisa Laboratório de Estudos sobre Trabalho, Cárcere e Direitos Humanos, da Universidade Federal de Minas Gerais (UFMG).

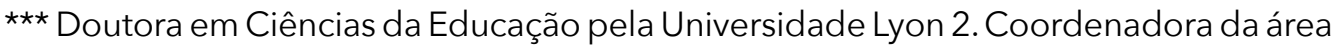
de Juventude, Políticas Públicas da Flacso-Brasil. Tem várias publicações na área de violência nas escolas, juventude e violência. Cocoordenadora da pesquisa Trajetórias e Juventude- Covid -19 e coordenadora do curso "Aperfeiçoamento em juventudes e educação" da Flacso, OEi e Unesco. Tem experiência na área de Ciências Sociais, com ênfase em Sociologia, atuando principalmente nos seguintes temas: gênero, educação, violências nas escolas, violência e juventude, juventude e políticas públicas, gangues e segregação social.

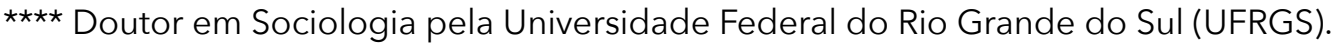
Professor da Universidade Federal do Recôncavo da Bahia (UFRB). Professor do Programa de Pós-Graduação em Ciências Sociais Cultura, Desigualdade e Desenvolvimento (PPGCS-UFRB). Líder do Grupo de Pesquisa Observatório Social da Juventude. Cumpriu estágio pós-doutorado no Departamento de Sociologia da USP. Recebeu o Prêmio da Coordenação de Aperfeiçoamento de Pessoal de Nível Superior (Capes) de Teses de Sociologia em 2010. 


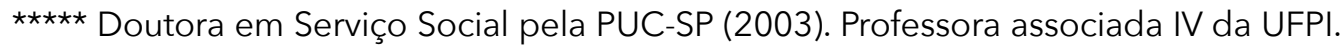
Tem experiência na área de Serviço Social, com ênfase em Serviço Social, atuando principalmente nos seguintes temas: cidadania, estado, políticas públicas; violência e direitos humanos; infância, adolescência e juventude; serviço social, assistência social e educação superior; gestão pública e controle social. É membro/pesquisadora do Nupec, coordenadora do Núcleo de Estudos e Pesquisas sobre Sociedade, Direitos e Políticas Públicas (NUDISPP) e membro do Núcleo de Estudos e Pesquisa sobre Serviço Social e Questão Social.

$\star \star \star \star \star \star$ Doutora em Ciências Sociais com ênfase em Antropologia pela -PUC-SP. Professora associada III do Departamento de Ciências Sociais da UFPI. Professora do Programa de Pós-Graduação em Sociologia e do Programa de Pós-Graduação em Arqueologia da mesma universidade, com estudos sobre as temáticas: gênero e geração; conservação e proteção ambiental; e arqueologia da paisagem e paleoambiente. Coordenadora do Grupo de Pesquisa Transdisciplinar sobre Corpo, Saúde e Emoções (Corpostrans) e membro/pesquisadora do Nupec.

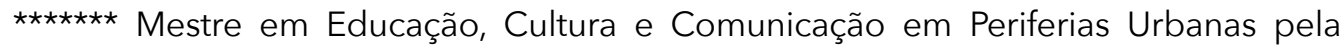
Faculdade de Educação da Baixada Fluminense da Universidade do Estado do Rio de Janeiro (FEBF-Uerj). Pesquisadora do Programa Estudos e Políticas sobre a Juventude da Flacso Brasil. Professora do curso de Comunicação Social da Universidade Salgado de Oliveira (Universo, Niterói-RJ). Jornalista e educomunicadora em projetos para adolescentes e jovens. Ativista e militante pelos direitos das juventudes.

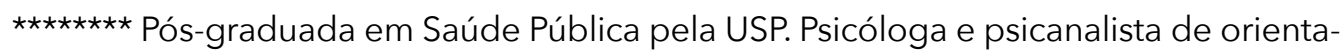
ção pichoniana. Pesquisadora do Laboratório de Inovação Social do Instituto de Saúde de São Paulo. Autora dos livros Fim de século: ainda manicômios? (1999), A cidadania negada: políticas públicas e formas de viver (2009) e Diálogos psicanalíticos sobre família e casal: as vicissitudes da família atual (2014).

Texto recebido em outubro de 2020; aprovado em novembro de 2020. 
ABRAMOVAY, Miriam; CASTRO, Mary Garcia; WAISELFISZ, Júlio Jacobo. Juventudes na escola, sentidos e buscas: por que frequentam?. Brasília: Flacso; OEl; MEC, 2015.

ANTUNES, Ricardo. O privilégio da servidão: o novo proletariado de serviços na era digital. São Paulo: Boitempo, 2020.

APESAR DE queda na renda, IDH municipal teve alta no Brasil em 2016-2017. Abruc, Brasília, 17 abr. 2019. Disponível em: <www.abruc.org.br/atualidade/noticia/apesar-de-queda-na-renda-idhmunicipal-teve-alta-no-brasil-em-20162017>. Acesso em: 10 out. 2020.

ARGENTINA UNIDA. El futuro después del covid-19. Buenos Aires: Argentina Futura, 2020.

BENJAMIN, Walter. Experiência e pobreza. Tradução Paulo Sérgio Rouanet. São Paulo: Brasiliense, 1987.

BRAH, Avtar. Diferença, diversidade, diferenciação. Cadernos Pagu, Campinas, n. 26, p. 329-376, jan.-jun. 2006.

BRASIL supera 150 mil mortes por covid-19. DW Brasil, 10 out. 2020. Disponível em: <www.dw.com/ pt-br/brasil-supera-150-mil-mortes-por-covid-19/a-55232306>. Acesso em: 13 out. 2020.

BUTLER, Judith. Actos performativos y constitución del género: un ensayo sobre fenomenología y teoría feminista. In: Debate Feminista, México, v. 18, out. 1998.

CHARLOT, Bernard. Du rapport au savoir: éléments pour une théorie. Paris: Anthropos, 1997.

CORONAVÍRUS: OMS declara pandemia. BBC News Brasil, São Paulo, 11 mar. 2020. Disponível em: <www.bbc.com/portuguese/geral-51842518>. Acesso em: 13 out. 2020.

DATASENADO: para pais, aulas remotas na pandemia prejudicaram educação. Senado notícias [online]. Brasília, 14 ago. 2020. Disponível em: https://www12.senado.leg.br/noticias/audios/2020/08/ datasenado-para-pais-aulas-remotas-na-pandemia-prejudicaram-educacao. Acesso em: 16 ago. 2020.

DELEUZE, Gilles. Espinosa: filosofia prática. Tradução Daniel Lins e Fabien Pascal Lins. São Paulo: Escuta, 2002.

DELORS, Jacques (Org.). Educação: um tesouro a descobrir. São Paulo: Cortez; Brasília: MEC, Unesco, 2001. Disponível em: <http://dhnet.org.br/dados/relatorios/a_pdf/r_unesco_educ_tesouro_descobrir. pdf>. Acesso em: 13 de out. 2020.

DESEMPREGO diante da pandemia tem alta de 20,9\% entre maio e julho, aponta IBGE. G1 [online]. 23 set. 2020. Disponível em: https://g1.globo.com/economia/noticia/2020/08/20/desempregodiante-da-pandemia-tem-alta-de-209percent-entre-maio-e-julho-aponta-ibge.ghtml. Acesso em 15 out. 2020.

DOLCE, Julia. Desigualdade social é fator de risco para mortes de crianças e adolescentes por covid-19 no país. Pública, São Paulo, 9 jun. 2020. Disponível em: <https://apublica.org/2020/06/desigualdadesocial-e-fator-de-risco-para-mortes-de-criancas-e-adolescentes-por-covid-19-no-pais/>. Acesso em: 13 out. 2020.

FERREIRA, Maria D’Alva Macedo. Significado do trabalho para os jovens em Teresina. In: A condição juvenil em Teresina. LUZ, Lila Cristina Xavier et al. Teresina: Edufpi, 2013.

FORACCHI, Maria Alice, O estudante e a transformação da sociedade brasileira. São Paulo: Nacional, 1965.

FREUD, Sigmund. Obras completas: el porvenir de una ilusion. Buenos Aires: Amorrortu, 1996. v. 21. 
HARARI, Yuval Noah. Notas sobre a pandemia: e breves lições para o mundo pós-coronavírus. São Paulo: Companhia das Letras, 2020.

IBGE. Pesquisa Nacional por Amostra de Domicílios Contínua - PNAD Contínua. Trimestre móvel: jun-jul-ago/2020 Rio de Janeiro: IBGE, outubro de 2020. Disponível em:https://ftp.ibge.gov.br/ Trabalho_e_Rendimento/Pesquisa_Nacional_por_Amostra_de_Domicilios_continua/Mensal/Quadro_ Sintetico/2020/pnadc_202008_quadroSintetico.pdf. Acesso em: 16 out 2020a.

IBGE. Indicadores IBGE: Pesquisa Nacional por Amostra de Domicílios Contínua - segundo trimestre de 2020. Rio de Janeiro: IBGE, 28 ago. 2020. Disponível em: <https://static.poder360.com. br/2020/08/pnad-continua-do-2o-trimestre.pdf>. Acesso em: 15 out. 2020b.

KREIN, José Dari; BORSARI, Pietro. Coronacrise: a pandemia, a economia e a vida. IE-Unicamp, Campinas, 11 maio 2020. Disponível em: <www.economia.unicamp.br/covid19/pandemia-edesemprego-analise-e-perspectivas>. Acesso em: 13 out. 2020.

MORIN, Edgar. Os sete saberes necessários à educação do futuro. São Paulo: Cortez; Brasília: Unesco, 2000.

NUNES, Letícia; ROCHA, Rudi; ULYSSEA Gabriel. Vulnerabilidades da população brasileira à covid-19: desafios para a flexibilização do distanciamento social. Nota Técnica, n. 9. São Paulo: leps, maio 2020. Disponível em: <http://ieps.org.br/wp-content/uploads/2020/05/NT9-IEPS.pdf>. Acesso em: 15 out. 2020.

OLIVEIRA, João Manuel de. Desobediência de gênero. Salvador: Devires, 2017.

OMS. Constituição da Organização Mundial da Saúde. Organização Mundial da Saúde, out. 2006. Disponível em: <http://bibliobase.sermais.pt:8008/BiblioNET/Upload/PDF2/0902_ Constituic\%CC\%A7a\%CC\%83o\%20da\%20Organizac\%CC\%A7a\%CC\%83o\%20Mundial\%20da\%20 Sau\%CC\%81de.pdf>. Acesso em: 10 out. 2020.

OPAS BRASIL. Opas: alguns países mostram picos na transmissão de covid-19, especialmente entre jovens. Brasília, 7 out. 2020. Disponível em: <https://www.paho.org/bra/index.php?option=com_co ntent\&view=article\&id=6303: opas-alguns-paises-mostram-picos-na-transmissao-de-covid-19especialmente-entre-jovens\&ltemid=812>. Acesso em: 13 out. 2020.

PAIS, José Machado. Ganchos, tachos e biscates: jovens, trabalho e futuro. 2. ed. Lisboa: Ambar, 2016.

PIRES, Luiza Nassif; CARVALHO, Laura; XAVIER, Laura de Lima. Covid-19 e desigualdade: a distribuição dos fatores de risco no Brasil. 2020. Disponível em: <www.researchgate.net/publication/340452851_ COVID-19_e_Desigualdade_no_Brasil>. Acesso em: 13 out. 2020.

PORTELLI, Alessandro. Um trabalho de relação: observações sobre a história oral. Tradução Lila Cristina Xavier Luz. Revista Trilhas da História, Três Lagoas, v. 7, n. 13, p. 182-195, jul.-dez. $2017 .$.

RAMOS, Lauro; LAMEIRAS, Maria Andreia Parente; CAVALCANTI, Marco Antônio. Pnad Covid-19: divulgação de 16/10/12020 - principais destaques. Carta de Conjuntura, n. 49. Ipea, 16 out. 2020. Disponível em: <www.ipea.gov.br/cartadeconjuntura/index.php/category/mercado-de-trabalho/>. Acesso em: 13 out. 2020.

REDE DE PESQUISA SOLIDÁRIA. Covid-19: políticas públicas e as respostas da sociedade. Boletim Políticas Públicas \& Sociedade, São Paulo, n. 14, 3 jul. 2020. Disponível em: <https://jornal.usp.br/ wp-content/uploads/2020/07/BoletimPPS_14_3julho.pdf>. Acesso em: 13 out. 2020.

SABOIA, João; BAETA, Fernanda; GOMES, Gustavo. Desalentados no Brasil: caracterização e evolução no período 2014/2019. Rio de Janeiro: UFRJ, abr. 2020. (Texto para discussão 003/2020). Disponível em: <www.ie.ufrj.br/images/IE/TDS/2020/TD_IE_003_2020_SABOIA_BAETA_GOMES. pdf $>$. Acesso em: 13 out. 2020. 
SANTOS, José Alcides Figueiredo. Desigualdades e interações de classe social na saúde no Brasil. Dados, Rio de Janeiro, v. 63, n. 1, 8 maio 2020. Disponível em: <http://www.scielo.br/scielo. php?script=sci_arttext\&pid=S0011-52582020000100201\&lng=en\&nrm=iso >. Acesso em: 13 out. 2020.

SEGATO, Rita Laura. Coronavirus: todos somos mortales - del significante vacío a la naturaleza aberta de la historia. In: ARGENTINA UNIDA. El futuro después del covid-19. Buenos Aires: Argentina Futura, 2020.

THE WORLD BANK. A covid-19 lança a economia mundial na pior recessão desde a Segunda Guerra Mundial. The World Bank, 8 jun. 2020. Disponível em: <https://www.worldbank.org/pt/news/ press-release/2020/06/08/covid-19-to-plunge-global-economy-into-worst-recession-since-world-warii>. Acesso em: 13 out. 2020.

UNESCO. Políticas públicas de/para/com as juventudes. Brasília: Unesco, 2004.

VÍRUS "rejuvenesceu": reabertura mudou perfil de vítimas da covid-19, diz Saúde. IG, 21 ago. 2020. Disponível em: <https://saude.ig.com.br/2020-08-21/virus-rejuvenesceu-reabertura-mudou-perfil-devitimas-da-covid-19-diz-saude.html>. Acesso em: 13 out. 2020.

WEISHEIMER, Nilson. A situação juvenil na agricultura familiar. Curitiba: Editora CRV, 2019.

WHO. Coronavirus disease 2019 (covid-19): situation report 43. World Health Organization, 3 mar. 2019. Disponível em: <www.who.int/docs/default-source/coronaviruse/situation-reports/20200303sitrep-43-covid-19.pdf?sfvrsn=2c21c09c_2>. Acesso em: 13 out. 2020. 